\title{
EFFECTIVENESS OF FDI, TECHNOLOGICAL GAP AND SECTORAL LEVEL PRODUCTIVITY IN THE VISEGRAD GROUP
}

\author{
Kamil MAKIEŁA (D) ${ }^{*}$, Liwiusz WOJCIECHOWSKI (D) ${ }^{2}$, Krzysztof WACH ${ }^{(D)}$ \\ ${ }^{1}$ Department of Econometrics and Operational Research, Cracow University of Economics, \\ Krakow, Poland \\ ${ }^{2,3}$ Department of International Trade, Cracow University of Economics, Krakow, Poland
}

Received 12 May 2020; accepted 22 November 2020

\begin{abstract}
The objective of this paper is to investigate the impact of foreign direct investment (FDI) on economic growth and productivity in sectors of the Visegrad Group one decade after their accession to the EU. In order to account for sample heterogeneity, as well as productivity differences, we construct a generalized true random-effects model with varying efficiency distribution. We find that FDI has a positive impact on the Visegrad Group's sectors and that its effectiveness depends upon the technological gap between the host and home economy. There are three sources of this positive impact: (i) sectoral output and labour productivity growth, (ii) more effective use of input factors, and via (iii) higher efficiency component of the total factor productivity (TFP). These sources form a three-way transmission mechanism through which FDI can impact economic growth conditioned upon FDI effectiveness due to the technological gap.
\end{abstract}

Keywords: FDI, productivity, TFP, Visegrad Group, GTRE, panel data.

JEL Classification: C23, F21, O47, C11.

\section{Introduction}

The role of foreign direct investments (FDI hereafter) in spurring economic development has been of major research interest for many decades. It is generally anticipated that FDI is growth enhancing. Theoretical considerations usually focus on FDI's contribution to growth via capital formation (see, e.g., MacDougall, 1960; Thompson, 2008), or various mechanisms and transfers through which FDI impacts productivity (see, e.g., Findlay, 1978; Dunning, 1973; Wang \& Blomstrom, 1992; Barrios et al., 2005; Liu, 2008; among others). However, the theory does not provide an unequivocal and full answer regarding the impact of these investments on host economies, especially considering the potentially diverse effects they may have in the short and long time horizon on productivity.

${ }^{*}$ Corresponding author. E-mail: kamil.makiela@uek.krakow.pl

Copyright (c) 2020 The Author(s). Published by Vilnius Gediminas Technical University

This is an Open Access article distributed under the terms of the Creative Commons Attribution License (http://creativecommons. org/licenses/by/4.0/), which permits unrestricted use, distribution, and reproduction in any medium, provided the original author and source are credited. 
FDI's attractiveness, besides pure face value of an investment, is due to the generated spillover effects through various forms of technology and know-how transfers, which are said to induce productivity growth, especially in developing countries (Azman et al., 2010; Almfraji \& Almsafir, 2014). This is widely considered to be conditioned on the host economy's 'absorptive capacity', which is as a broad set of characteristics related to the level of institutional and economic development required to benefit from FDI spillovers (Durham, 2004), or even for FDI spillovers to exist at all (Hanousek et al., 2011). Typical indicators of absorptive capacity characterize maturity of financial markets, institutional development, trade openness, human capital or the technological gap, which expresses the technological difference between the home country (or firm) and the host country (see, e.g., Glass \& Saggi, 1998; Hong et al., 2019).

Empirical research on the FDI, economic growth and productivity nexus is also inconclusive. FDI's role is often found to be conditioned on additional factors like the abovementioned absorptive capacity (see, e.g., Durham, 2004; Alfaro et al., 2009; Azman et al., 2010; Wach \& Wojciechowski, 2016a, 2016b; Orlic et al., 2018; Li \& Tanna, 2019), or even political risk assessment (Jiang et al., 2019). In general, one can distinguish two "channels" through which FDI can affect growth: (i) a direct one via accumulation of input factors (e.g., investments which lead to domestic capital formation; see, e.g., Mallick \& Moore, 2008) and (ii) an indirect one via total factor productivity (TFP) growth (increased productivity, new technologies, know-how, etc.). While there is some discerning empirical evidence about the positive "direct" impact on economic growth, far less evidence has been found on FDI's "indirect" effect on productivity (Makieła \& Ouattara, 2018).

Most empirical research on FDI has been done either at a firm level, with a focus on one particular country (or one industry), or at an international level using cross-section or panel data; see, e.g., Iamsiraroj and Ulubasoglu (2015), Almfraji and Almsafir (2014), Hanousek et al. (2011) or Meyer and Sinani (2009) for an overview. Although the fact that different sectors of an economy may have different potential for foreign investments was suggested a long ago (Hirschman, 1958), little research has been devoted to cross-country sectoral level analyses (see, e.g., Barrell \& Holland, 2000; Bijsterbosch \& Kolasa, 2010; Vu \& Noy, 2009; Doytch \& Uctum, 2011; or Cipollina et al., 2012). Hence, as Orlic et al. (2018) state "Although a great deal of research has been devoted to understanding of FDI spillovers, some significant knowledge gaps remain".

Given the aforementioned considerations, the primary objective of this study is to explore the often debated "indirect" channel at the sectoral level (though we do not neglect the direct one). In particular, our novel approach relies on recent advancements in stochastic frontier analysis that allow us to study the impact of FDI on sectoral level productivity in the face of variable absorptive capacities in the Visegrad Group countries (V4 hereafter) after their accession to the European Union (2004-2013). We have chosen to focus on the V4 group due to a mix of favourable conditions and unique characteristics of the region in recent years. First, the Czech Republic, Hungary, Slovakia and Poland all became members of the EU in 2004. Upon entering the EU, they were still fairly underdeveloped economies, but today, by most accounts, they are regarded as high income countries (although they are still catching-up economies by EU standards). The transition they went through after accessing the EU 
is not only impressive but largely the result of considerable amounts of FDI. Second, the fact that these countries are members of the EU also has a practical dimension - the availability of reliable and cross-country comparable economic data, which are especially difficult to come by if one is seeking a sectoral level breakdown. Every EU member state is obligated to provide the European Commission with various economic indicators, which are produced according to a unified methodology described in the European System of Accounts (ESA). Since their accession in 2004, the V4 economies are no exception to this rule. Third, V4 economies are similar and different at the same time, which is a big benefit for such analysis. That is, they are similar because (i) they share similar post-communism economic history, transforming from a centrally oriented economy to a modern market-based one; (ii) they are at a comparable level of economic, financial and institutional development; (iii) they share cultural similarities, e.g., in terms of governance and work culture; and (iv) they are closely linked geographically. These commonalities are not without merit when analysing FDI because many characteristics related to the absorptive capacity (trade openness, institutions, financial markets, geography etc.) can be regarded as (approximately) similar. This in turn allows us to focus on one particular venue of absorptive capacity that is especially interesting for productivity analysis - the technological gap. At the same time, however, there are considerably different, e.g., in terms of economic size, population and density. Furthermore, for a sectoral level analysis it is not only the whole economy that matters but also the (relative) size of each sector in it, and this can differ significantly from one V4 country to another. Such diversity is particularly valuable from an analytical viewpoint. This is because we want objects which are relatively homogenous (in terms of production technology etc.) and yet provide a significant-enough variation with respect to the characteristics we want to analyse. To sum up, the fact that we deal with countries that are similar from one point of view (economic history, development, culture, geography, membership in the EU) but different from another (e.g., size, sectoral composition, different FDI levels), and which experienced a large growth in FDI around the same time makes the V4 region particularly appealing.

There are three main contributions of this study. First and foremost, we address the still-existing knowledge gap about the FDI effectiveness-economic growth-productivity nexus. In particular, we investigate how FDI impacts sectoral productivity in terms of both, labour productivity and the total factor productivity (TFP). In doing so, we investigate if FDI effectiveness is conditioned upon the size of the technological gap, which could be a relevant proxy for the sectoral absorptive capacity in V4. Second, although many previous studies have explored the impact of FDI on productivity of various economies, this study is a cross-country panel data analysis carried out at the sectoral level, which is still very rare in the FDI literature. Results of firm-level studies are likely conditioned on the unique characteristics of the country (or its market), while results of country-level studies may be driven by difficult to control sample heterogeneity (e.g., some inconclusive results at the country level may be due to variable involvement of FDI between sectors in those countries). Third, the originality of this article also lies in its analytical approach, i.e., the construction of a stochastic frontier model that has been tailored-made for sectoral level panel data analysis among different countries, as well as its estimation procedure which relies on Bayesian inference. To our knowledge this is the first time these techniques have been implemented in 
the FDI literature. They allow us to effectively verify the impact of FDI on sectoral technical (in)efficiency and productivity using panel data approach, taking into account differences between sectors, countries and time.

The article progresses as follows. The next section describes literature review relevant to the hypotheses developed to study sectors of the V4. Section 2 describes the modelling strategy and the data. In section 3, we present the empirical findings and discussion. The last section summarizes conclusions and suggests venues for further research.

\section{Prior studies and hypotheses development}

There is a general consensus in the literature regarding an interplay between FDI, production and productivity in the host economy. However, the exact nature of it still remains an open question. FDI is commonly considered a catalyst for economic growth and social development, especially in emerging and transition economies (Melnyk et al., 2014). FDI's effects can be divided into categories (economy, policy, social, technology and science, competitiveness) and the direction of external effects (positive, negative, neutral). From the theoretical perspective, the net effect of FDI is not unequivocal. Potential positive external effects of FDI include, among others, filling the gap between the desired level of investment and domestic savings, strengthening the national currency, increase in budget revenues, increase in employment and labour productivity, and improvements of the image of the country and its position in international rankings. Negative effects, however, may be observed in terms of the reduction of the rate of savings and domestic investment, the limitation of the sovereignty and the effectiveness of the national macroeconomic policy, and reduction of employment.

The empirical literature is filled with studies about FDI's impact on the host economy mainly within a single country framework. For example, Żukowska-Gagelmann (2000) found that a higher share of foreign capital in Polish manufacturing negatively affects local firms, though this effect may differ between firms and industries. Djankov and Hoekman (2000) and Stancik (2010) analysed Czech companies and concluded that (forward) positive spillovers are the most often to be observed; however, the type of investment matters in terms of FDI's impact on growth and productivity. In Lithuania, Javorcik (2004) found that the positive spillovers from FDI do appear, but are associated with shared endeavours, not with fully owned foreign investments. In Ireland, Barrios et al. (2005) found that there are positive and negative effects of FDI at the firm level but positive spillovers tend to be larger. In the UK, however, Haskel et al. (2007) found that the costs of incentives in the UK manufacturing granted by the government tend to outweigh productivity gains due to FDI presence. Wojciechowski (2016a, 2016b) indicated the importance of FDI in Poland both for the entire economy and for the processing industry. However, Kolasa (2008) found that positive FDI spillovers in Poland are conditioned on R\&D intensity in domestic firms. In Romania, Javorcik and Spatareanu (2011) conclude that FDI spillovers are conditioned on the origin of home country, which is likely due to tariff regulation. In China, Lin et al. (2011) and Liu et al. (2016) found that the strength of FDI spillovers (on productivity) is conditioned on the levels of human capital. In Turkey, Javorcik et al. (2018) studied manufacturing firms and concluded that the presence of foreign companies boosts upgrades in production structure 
and its sophistication; however, little is explored about actual productivity gains (though labour productivity is among control variables in the study). Orlic et al. (2018) conduct a cross-country analysis of firms in manufacturing sectors and conclude that local manufacturers benefit from backward spillovers in manufacturing and forward spillovers of FDI in services. Finally, a meta-analysis by Hanousek et al. (2011), a mix of firm and country-level studies, found that there are positive (backward) spillover effects as well as negative (forward) spillovers. The authors also found that direct and indirect FDI effects may weaken over time and that studies based on cross-section data tend to have an upward bias, thus finding more productivity spillovers than panel data studies. These examples do not even scratch the surface of the enormous amount of research done at the firm-level. It is obvious that firm-level studies lack generality, and thus tend to produce various and mixed conclusions as to the effects of FDI, e.g., dependently on the country of origin.

On the country level, empirical results are similarly inconclusive. In a comprehensive meta-analysis covering 108 empirical studies, Iamsiraroj and Ulubasoglu (2015) stated that generally, four out of ten studies report an insignificant relationship between FDI and productivity. Mastromarco and Ghosh (2009) found that for developing countries FDI's impact is conditioned on human capital. Makieła and Ouattara (2018) studied the transmission channels through which FDI impacts economic growth. They found that FDI affects growth via inputs accumulation component but not that much through the total factor productivity (TFP). Li and Tanna (2019) suggested that a robust impact of FDI on TFP growth at the country level can be found but only if some additional, institutional and human capital factors are taken into account. Similar conclusions can be found, e.g., in a meta-analysis by Meyer and Sinani (2009).

Only a handful of studies can be found on an industry or sectoral level, and even fewer involving several countries (cross-country). Among the first to conduct such an analysis are probably Barrell and Holland (2000) who focused on 11 manufacturing sectors in Czech Republic, Hungary and Poland. They found that FDI's presence is positively correlated with labour productivity. Bijsterbosch and Kolasa (2010) also studied sectoral labour productivity in eight central and eastern European EU Member States in 1995-2005 (thus mostly prior their accession to the EU). They found signs of productivity convergence and that FDI is important to productivity growth. Vu and Noy (2009) analysed highly developed countries and concluded that overall FDI has a positive impact on GDP growth, also indirectly through its interaction with labour. However, this varies significantly between industries as well as countries and in some sectors they find no evidence that FDI is growth enhancing. Doytch and Uctum (2011) studied manufacturing and services sectors in a relatively large sample of countries. They find that although at the aggregate (country) level FDI is growth enhancing different components of FDI flows have different effects at the sectoral level. Fillat and Woerz (2011) tried to reconcile the FDI vs. economic growth nexus by using panel data from eight industries in thirty five countries. They concluded that the stage of development is crucial for FDI to impact growth. Hanafy and Marktanner (2019) studied Egyptian industries (thus the study only involved one country). They also found that FDI does not have an unconditional effect on growth. In case of Egypt, it is the level of domestic private investment that matters. Finally, a robust and unconditional effect on growth as well as productivity is found by Cipollina et al. (2012). In a panel study involving fourteen manufacturing sectors in twenty two 
developing and developed countries the authors concluded that FDI's contribution to growth comes from factors' accumulation as well as TFP growth (thus direct and indirect channel).

To sum up, the theory about the spillover effects of FDI is not unequivocal, and the empirical research, which tries to fill the gap, is still largely inconclusive. This leads to the formation of the first hypothesis in our study of the V4 group H1: Increased FDI presence in a given sector is associated with increased productivity in this sector. Countries of the V4 group have been analysed in a number of FDI studies (Żukowska-Gagelman, 2000; Barrell \& Holland, 2000; Djankov \& Hoekman, 2000; Konings, 2001; Sgard, 2001; Bijsterbosch \& Kolasa, 2010; Melnyk et al., 2014; Gunther \& Kristalova, 2016; among others). These papers, however, produced conflicting results in this regard. In fact, most conclude that negative effects are dominant or that positive effects are conditional. Not to mention that the above-listed papers are largely about firm-level studies on one individual country and thus cannot provide the necessary generality for the entire V4 group.

Since the V4 is a rather homogenous group with respect to most absorptive capacity indicators (e.g., trade openness, financial markets and institutional development, human capital), it gives us the opportunity to explore the role of the technological gap mentioned before (also, most aforementioned indicators - if not all - are measured at a country level and are therefore of little use in a sectoral level analysis involving only four countries). That is why the following hypothesis is also to be addressed: H2: The size of the technological gap has a significant impact on the efficiency of using FDI, and thus it is a good indicator of absorptive capacity at the sectoral level. According to Findlay (1978), the rate of technological progress is an increasing function of the technological gap between the host and home country and an increasing function of acquired FDI. In their theoretical model, Wang and Blomstrom (1992) point out that the relative rate of technology transfers to the host country is instrumental in closing the technology gap. Glass and Saggi (1998) show that the technological gap between the host country and the home country of FDI can be treated as an indicator of the absorption capacity of firms (the greater the distance, the lower the quality of technology transferred and the smaller potential benefits accompanying FDI). Kokko et al. (1996) show that unless the gap is too high, local firms can benefit from the activities of foreign entities in the common market. That $\mathrm{s}$ why, using hypothesis $\mathrm{H} 2$ we wish to investigate if the relationship between FDI and productivity at the sectoral level - hence at some level of aggregation and therefore generalization - is indeed dependent on the technological gap between home and host countries.

\section{Modelling strategy and data}

\subsection{The model}

Most contemporary research on FDI relies, to some degree, on the theory of aggregate production function (APF hereafter). Within an APF-based framework, economic theorists usually postulate that FDI can (i) directly affect production of an economy as an input (e.g., FDI stock being a relevant input factor, apart from conventionally regarded main inputs like capital and labour; see, e.g., Egger \& Pfaffermayr, 2001; Kosztowniak, 2013; Apostolov, 2016). Also, as mentioned in the previous section the technological gap (GAP hereafter) between 
the host and home economy is likely an important factor in determining effective use of FDI. Furthermore, FDI can induce production indirectly by (ii) influencing the effectiveness of the main inputs or (iii) via the total factor of productivity TFP (see Makieła \& Ouattara, 2018). Since we do not wish to decide a priori which notion about FDI's influence is correct, we devise the following system of two equations:

$$
\left\{\begin{array}{l}
Q_{i j t}=G\left(\beta ; K_{i j t}, L_{i j t}, F D I_{i j t}, G A P_{i j t}\right) e^{\varepsilon_{1, i j t}} \\
F D I_{i j t}=H\left(x_{i j t}\right) e^{\varepsilon_{2, i j t}}
\end{array},\right.
$$

where: $Q$ - production; $G$ - a standard APF-type relation in the host economy; $K$ - capital stock; $L$ - labour; $H$ - a deterministic process in the home economy; FDI - foreign direct investment; GAP - technological gap; $x$ - a vector of FDI determinants; $e^{\varepsilon_{1, i j t}}, e^{\varepsilon_{2, j i t}}-$ stochastic components (in a multiplicative form); $i$ - the country; $j$ - the sector; $t$ - time period (year).

We assume independence between $\varepsilon_{1}$ and $\varepsilon_{2}$, which is reasonable since both error terms have different sources of origin (host and home economy). Since this study relies on Bayesian inference to estimate the parameters, the reader should note that parameters of both equations are a priori independent of each other. This leads to posterior independence of the parameters between the two equations, provided that there are no explicit (one or two-way) dependencies described by the deterministic processes in $G($.$) and H($.$) . As a result, the first$ equation can be estimated as a standalone equation without information from the second one and the other way around. This feature allows us to conveniently concentrate on the first equation and maintain a clear focus of subsequent sections of the paper. Nonetheless, we should note that both equations describe an important theoretical aspect of the FDI modelling principle. The first equation in (1) we shall refer to as the host equation. It is described by a "standard" APF-type relation in $G($.$) , which shows how production is generated in a$ sector of the host economy. The second equation is the home equation which describes investors' decision making process in the home economy as a result of a deterministic function in $H\left(x_{i t}\right)$ and a stochastic component (in $\left.e^{\varepsilon_{2, i j t}}\right)$. The role of $H\left(x_{i t}\right)$ is to describe FDI as a result of information in vector $x_{i t}$, which in turn contains a list of possible FDI determinants to be explored. The function itself can be either parametric or nonparametric and its estimation may, or may not, depend on information from the host equation. For example, Su et al. (2018) explore parametric dynamic panel form of $H($.$) while Wojciechowski and Makieła$ (2019) include TFP in $x_{i t}$, which is a latent variable in the host equation. The latter proposal would create a one-way estimation dependency, i.e., we need to "know about" equation one (host) in order to make inference about equation two (home). The argument is that investors' decisions about FDI, at least partially, rely on the observed productivity in the host economy. Such one-way dependence can be further explored (e.g., in spirit of Su et al. (2018); who also use Bayesian techniques), or removed entirely given particular assumptions made about $H\left(x_{i t}\right)$. This is, however, beyond our interest here and some aspects of the home equation have already been addressed in Su et al. (2018) as well as Wojciechowski and Makieła (2019).

Since we wish to explore the impact of FDI on the host economy (the aforementioned points $\mathrm{i}$-iii at the beginning of this section), we focus on the host equation:

$$
Q_{i j t}=e^{\beta_{0}} K_{i j t}^{*} \beta_{1} L_{i j t}^{*} \beta_{2} F D I_{i j t}^{*} \beta_{3} e^{\beta_{5} t} e^{\varepsilon_{1, i j t}} .
$$


so that $G($.$) . in (1) is an extended Cobb-Douglas type relation with a compound error term$ $\varepsilon_{1, i j t}$. First, we shall discuss the parametric part. In order to transform observed inputs to effective inputs and analyse how FDI may contribute to growth through them, the following convolutions for effective inputs are made: $K_{i j t}^{*}=\left[K_{i j t} e^{\gamma_{1} F D I_{i j t}}\right]$ and $L_{i j t}^{*}=\left[L_{i j t} e^{\gamma_{2} F D I_{i j t}}\right]$, where $K$ and $L$ are observed capital stock and labour levels (see Koop et al., 2000). Thus, effective inputs $K^{*}, L^{*}$ are dependent on an adjustment (scaling) factor in which FDI is an explanatory variable. This allows us to ascertain how (and if) FDI stimulates the main inputs' effectiveness in the host economy and thus their overall productivity. The economic rationale behind this approach is that increased FDI presences in a sector should bring in more knowhow, human capital etc., and thus we should be witnessing more "effective" utilization of capital and labour.o make our derivations simpler, we assume $\gamma_{1}=\frac{\gamma_{0}}{\beta_{1}}, \gamma_{2}=\frac{\gamma_{0}}{\beta_{2}}$. This means that FDpact on effective inputs relies on a "free" parameter $\gamma_{0}$ and subsequent production elasticities (of capital and labour). Due to economic regularity conditions, production elasticities are always positive, and thus $\gamma_{0}$ determines the impact of FDI on capital as well as labour productivity. If $\gamma_{0}>0$, FDI increases the effectiveness of the main inputs in the host economy; $\gamma_{0}<0$ otherwise. Inference about this parameter will be useful in ascertaining hypothesis $\mathrm{H} 1$ about the role of FDI in productivity growth.

Furthermore, as opposed to a standard two-input Cobb-Douglas production function, we assume that FDI affects economy as a third factor of production. We also allow the impact of FDI to be moderated by the technology gap. Economic rationale behind such treatment has been explored in previous sections of the paper. Thus, we have $\left.F D I_{i j t}^{*}=\left[F D I_{i j t} e^{\gamma_{3} \operatorname{lnGAP}}\right]_{i j t}\right]^{\beta_{3}}$, which means that we allow the "effective" FDI input (FDI $\left.{ }^{*}\right)$ to be dependent on a scaling factor, in which GAP is an explanatory variable. The value of parameter $\gamma_{3}$ determines the influence of GAP on FDI effective use in the host economy. If $\gamma_{3}>0$, this influence is positive (higher GAP implies more effective FDI use). This parameter is particularly useful in examining hypothesis $\mathrm{H} 2$ regarding the role of GAP as a measure of absorptive capacity. Parameter $\beta_{3}$ also has a standard production elasticity interpretation and as such informs us about the "direct" impact of FDI on economic growth.

The above convolution (effective factor correction) results in a bilinear model in (2) with respect to the logs of the original variables (thus the model is nonlinear with respect to original variables: Q, K, L, FDI, GAP; a known feature of exponential class functions such as Cobb-Douglas):

$$
\ln Q_{i j t}=\beta_{0}+\beta_{1} \ln K_{i j t}+\beta_{2} \ln L_{i j t}+\beta_{3} \ln F D I_{i j t}+\beta_{4} G A P_{i j t}+\beta_{5} t+\gamma_{0}\left(2 F D I_{i j t}\right)+\varepsilon_{1, i j t},
$$

where $\beta_{4}=\beta_{3} \gamma_{3}$ (i.e., we have $\gamma_{3}=\frac{\beta_{4}}{\beta_{3}}$ ). Thus, even thougGAP is not directly linked as a production factor parameter $\beta_{4}$ represents the impact of GAP on aggregate product. Moreover, some studies analyse the impact of FDI and GAP on Q/L (production per labour unit also known as partial productivity of labour or just [partial] labour productivity - "LP”), often under constant returns to scale (CRS). Since FDI's impact on labour productivity (LP) is of interest in this study (apart from the TFP) we can rewrite the host equation to explore Q/L: 
$\ln \frac{Q_{i j t}}{L_{i j t}}=\beta_{0}+\beta_{1} \ln K_{i j t}+\left(\beta_{2}-1\right) \ln L_{i j t}+\beta_{3} \ln F D I_{i j t}+\beta_{4} G A P_{i j t}+\beta_{5} t+\gamma_{0}(2 F D I)_{i j t}+\varepsilon_{1, i j t}$.

The only difference in analysing $\mathrm{Q} / \mathrm{L}$ as opposed to $\mathrm{Q}$ (in $3 \mathrm{a}$ ) is the elasticity of labour. It should be noted that there is no need in ( $3 \mathrm{~b})$ to impose constant returns to scale (CRS) restrictions. In general, one could impose it should there be such a need, and of course this would simplify (3b) a bit. However, there are at least three reasons why we do not impose CRS here. First, constant returns may not be an adequate restriction for sectoral level analysis since we deal more with a meso than a macro scale analysis in this case. Second, since we use Bayesian inference we can easily move between different re-parametrizations of (2) and check any restriction of interest instead of just imposing it. Third, from a purely statistical viewpoint constant returns to scale is a model restriction, which in our case, does not lead to any particular gain. Thus, we use the unrestricted model.

Now, let us turn to the stochastic component in (2), which is of great importance here. In order to account for the sample heterogeneity and cross-sample productivity differences in the total factor productivity (TFP hereafter), we introduce the following compound error term to capture differences in country-sector TFP:

$$
\varepsilon_{1, i j t}=v_{i j t}+\alpha_{i j}-\eta_{i j}-u_{i j t} .
$$

Apart from a standard random disturbance $v_{i j t} \sim i . i . N\left(0, \sigma_{v}^{2}\right)$, which is usually not part of TFP, we consider an individual, country and sector-specific random effect $\alpha_{i j} \sim i . i . N\left(0, \sigma_{\alpha}^{2}\right)$, typical for panel data models. Furthermore, since we are interested in analysing cross-observation differences in productivity and productive efficiency, and thus how TFP is affected by FDI to further explore hypothesis $\mathrm{H} 1$, we also include two so-called stochastic frontier components (see, e.g., Fried et al., 2008; and citations therein). The first one, $\eta_{i j} \sim$ i.i. $N^{+}\left(0, \sigma_{\eta}^{2}\right)$ , is known as persistent inefficiency and captures constant structural differences in TFP via technical efficiency between countries and sectors. The second one $\left(u_{i j t}\right)$ is called transient inefficiency and allows us to capture TFP changes in time. Similar stochastic frontier analysis models are often used in productivity studies nowadays (see, e.g., Makieła (2014), or Makieła and Ouattara (2018), and citations therein).

The aforementioned stochastic structure formulates the so-called generalized true random effects model (GTRE; see, e.g., Colombi et al., 2014; Tsionas \& Kumbhakar, 2014; Badunenko \& Kumbhakar, 2016; Filippini \& Greene, 2016; Makieła, 2017a). Within this structure, we are particularly interested in the transient component of the model, while the remaining components are there to control for sample heterogeneity as well as persistent cross-sector TFP differences. Transient inefficiency $\left(u_{i j t}\right)$ allows us to capture interaction between TFP and FDI not only across observations but more importantly in time. That is, we can assess how FDI affects TFP change in the host economy and its sectors. To do so, we further develop our model and assume that $u_{i j t} \sim i . \operatorname{Exp}\left(\lambda_{i j t}\right)$ and that

$$
\ln \lambda_{i, j, t}=g_{0}+g_{1} F D I_{i j t}
$$

which results in a distribution on $u_{i j t}$ that is different across observations (also time) and dependents on FDI. If $g_{1}<0$, FDI has a positive impact on TFP because it lowers inefficiency; $g_{1}>0$. otherwise. Inference about $g_{1}$ is also linked directly to hypothesis H1. Equation (5) 
formulates a standard Varying Efficiency Distribution (VED) component embedded within an advanced GTRE framework, which produces the GTRE-VED model used in this study.

To sum up, such model construction allows us to explore the impact of FDI on productivity both, through labour productivity (LP; via $\gamma_{0}$ ) and the total factor productivity (TFP; via $\left.g_{1}\right)$. Moreover, we can explore the influence of the technological GAP on FDI $\left(\right.$ via $\left.\gamma_{3}\right)$ as well as aggregate production in general (via $\beta_{4}$ ).

Due to the complex stochastic structure of the GTRE-VED model in (2-3ab), so we use Bayesian inference to estimate its parameters. Alternatively one could also use another well-established method, which is maximum likelihood (ML). Bayesian inference, though computationally more demanding, has several theoretical advantages: (i) we obtain exact small sample results (ML properties are asymptotic), (ii) we can integrate out any nuisance parameters since each is assigned a probability distribution; and (iii) we can focus on any quantity of interest and, e.g., report medians and interquartile ranges (as we do in Section 3.1). This way we can take better account for parameter uncertainty and that is why our choice is Bayesian inference. Also, following the arguments in Makieła and Mazur (2020a) we note that under "standard" priors (which we use in this paper) Bayesian SFA yields very similar results as regards frontier parameters, which are of key interest here.

We use a standard prior structure proposed for GTRE in Makieła (2017a) whereas for VED component we follow Koop et al. (1994, 1997); see also Makieła and Misztur (2012) or Marzec and Osiewalski (2008). We implement the estimatioprocedure using software devised for Bayesian Stochastic Frontier Analysis; see Makieła (2017a, 2017b). Two aspects are worth noting here. First, we do not simplify the computation burden and keep FDI as a continuous variable in the VED component. In particular, we use a Metropolis-Hastings step for drawing VED parameters $\left(g_{0}, g_{1}\right)$ and Gibbs sampling scheme for the remaining ones (see Koop et al. 1994; for more information). Second, since we deal with a production function, possible inputs endogeneity needs to be given some consideration. On the one hand, the assumption of exogenous regressors can be removed by taking account of the first order conditions of profit maximization (Tsionas \& Mallick, 2019). On the other hand, however, it should be noted that in order to properly estimate the host equation we only need weak exogeneity of inputs. This is not that restrictive and quite reasonable in an aggregate production function setting (Osiewalski et al., 2018). Furthermore, the potential endogeneity problem is marginalised (or even elevated) in this study due to the fact that, after all, we use proxies for sectoral level aggregates. These proxies are good but far from perfect measures of the real values of (maybe endogenous) inputs in those sectors, and as such they can be treated as their instruments.

In order to approximate the posterior characteristics of the model, we run 500000 draws with first 100000 discarded due to the chain burn-in phase.

\subsection{Bottlenecks in data acquisition}

The qualitative selection of the data is basically a quantitative compromise between their availability and empirical usefulness. Major limitations in constructing the dataset were (i) the availability of data on purchasing power parity deflators (PPPs) at the sectoral level (at the macroeconomic level they are widely available), (ii) the availability of data on capital inputs and (iii) the data on labour input. 
First, a cross-country comparative analysis, such as this one, requires us to use currency-based variables that are not only comparable over time but also adjusted for differences in purchasing power parities (PPPs). The lack of sector-specific PPP deflators can distort the image when comparing sectors of national economies between countries (see, e.g., Olislager \& Knijno, 2017, p. 46). Thus, sectoral Q, K and FDI all need to be expressed in the Purchasing Power Standard. Second, calculation methods for capital stock are complex and rely heavily on information about depreciation rates for different types of capital assets. Although we were fortunate enough to mostly rely on ready datasets from Eurostat, we could not go beyond the timespan in it. Third, data for labour (L) were initially considered in two categories: the number of hours worked and the number of people employed. Although the literature suggests that the first category is more appropriate, the availability of data forced us to use the number of people employed.

Due to the aforementioned limitations the final timespan of the analysis is 2004-2013. This is conditioned upon two premises. First, it is justified to start the analysis around the time of structural changes, which brought long-term consequences for the V4, i.e., their accession to the European Union. It should be noted that FDI flows to the so-called new EU Member States, including the V4, have been taking place since the 1990s. However, V4 witnessed a substantial increase in foreign capital inflows (especially in the pre-crisis period) upon - and after - entering the UE. This is likely due the fact that a decrease in investment risk was already expected when the V4 was entering the EU, or even before. Second, we wish to use a balanced panel dataset and numerous data deficiencies, especially for labour data, at the time of the analysis forced us to limit the timespan to 2013.

\subsection{The data used in the study}

In order to analyse the host equation discussed in the previous section, we use a balanced panel of sector level indicators of production (Q), capital stock (K), labour (L), foreign direct investment (FDI) and the technological gap (GAP) for 13 sectors in Czech Republic, Hungary, Slovakia and Poland, in which FDI was present in the timeframe analysed (2004-3013). Summary information about the variables and sectors (categorized by NACE classification) can be viewed in Tables A1 and A2 in the Appendix.

Production (Q) in this paper is proxied by real gross value added (GVA hereafter) in millions of chained linked PPPs (2005 base year). Such internationally comparable sectoral GVA is obtained by applying appropriate purchasing power parity (PPP) deflators and can be downloaded from Eurostat. The choice of GVA is dictated by the fact that there is no GDP data at a sectoral level and that GVA is strongly correlated with GDP. Gross capital stock in replacement costs is used to proxy capital stock $(\mathrm{K})$. This indicator as well as FDI are also expressed in millions of chained linked PPPs to maintain cross-country comparability and comparability with GVA. Labour input $(\mathrm{L})$ is proxied by the number of people employed. The model also uses the variable GAP, which is to express the distance between a given sector of one of the V4 countries and the analogous sectors of a highly developed economy in a given period. Since we deal with EU Member States (V4), GAP is constructed as a (distance) ratio of partial productivity of labour in the EU15 area's sector to the partial productivity of labour in the host economy's sector: 


$$
G A P_{i j t}=\frac{\frac{Q_{U E 15, j t}}{L_{U E 15, j t}}}{\frac{Q_{i j t}}{L_{i j t}}} .
$$

Considering that (i) a large share of foreign economic activity, and thus FDI inflows, in V4 economies is with EU15 area and that (ii) V4 goal is to achieve the level of EU15 development (most of EU's Cohesion Policy is designed towards this goal), this seems like a good proxy for ascertaining the technological gap. According to the variable construction, e.g., 2.5 for the manufacturing sector in Poland in 2012 means that the gross value added per employee (i.e. partial labour productivity) was at that time, on average, 2.5 times higher in the EU15 than in Poland. Thus, values below 1 indicate higher labour productivity of the sector from the V4 country compared to the level of labour productivity achieved on average in the "old 15".

Table 1 and Figure 1 summarize the raw statistical data gathered. In some aspects the analysed economies can be considered as rather homogenous; e.g., all countries have had similar experiences of centrally planned economy. Nevertheless, in other aspects they are indeed different. For example, Poland's (total) GVA and labour input is roughly seven times the size of Slovakia although the capital stock is only about 3.5 times higher. V4 countries have substantially different input-output mixes. What is more, there are substantial differences in terms of variables' dynamics over time across V4. While all economies grew in the analysed period, Slovakia's GVA increased by $4.2 \%$ annually in comparison to just $0.7 \%$ GVA increase in Hungary. Hungarian labour input actually dropped by $0.4 \%$ while Polish grew by over $1.3 \%$ annually, which is roughly twice as fast as in Slovakia and Czech Republic. When looking at plain data of FDI level one could say that Poland is the biggest FDI beneficiary. However, if we consider the size of the economy (e.g., FDI per worker) Poland is actually the last. And last but not least, while GAP in Poland, Slovakia and Czech Republic was dropping rather steadily throughout the analysed period, GAP in Hungary, though decreasing at first, eventually remained oscillatory at a certain level.

Table 1. Summary statistics for the Visegrad countries in 2004-2013 (source: own study based on Eurostat data)

\begin{tabular}{|l|c|c|c|c|}
\hline \multicolumn{1}{|c|}{ Category } & PL & CZ & SK & HU \\
\hline GVA country mean & 410512 & 160021 & 60553 & 103922 \\
\hline GVA avg. annual change (\%) & $3.9 \%$ & $2.3 \%$ & $4.2 \%$ & $0.7 \%$ \\
\hline CAPITAL country mean & 1528918 & 1336473 & 435147 & 897969 \\
\hline CAPITAL avg. annual change (\%) & $3.8 \%$ & $2.8 \%$ & $4.4 \%$ & $2.1 \%$ \\
\hline LABOUR country mean & 15076 & 5039 & 2168 & 4082 \\
\hline LABOUR avg. annual change (\%) & $1.3 \%$ & $0.6 \%$ & $0.7 \%$ & $-0.4 \%$ \\
\hline FDI country mean & 198038 & 99267 & 34199 & 82090 \\
\hline FDI avg. annual change (\%) & $11.1 \%$ & $7.9 \%$ & $9.8 \%$ & $5.5 \%$ \\
\hline GAP country mean & 2.08 & 1.77 & 2.03 & 2.20 \\
\hline GAP avg. annual change (\%) & $-2.0 \%$ & $-1.1 \%$ & $-2.8 \%$ & $-0.6 \%$ \\
\hline
\end{tabular}



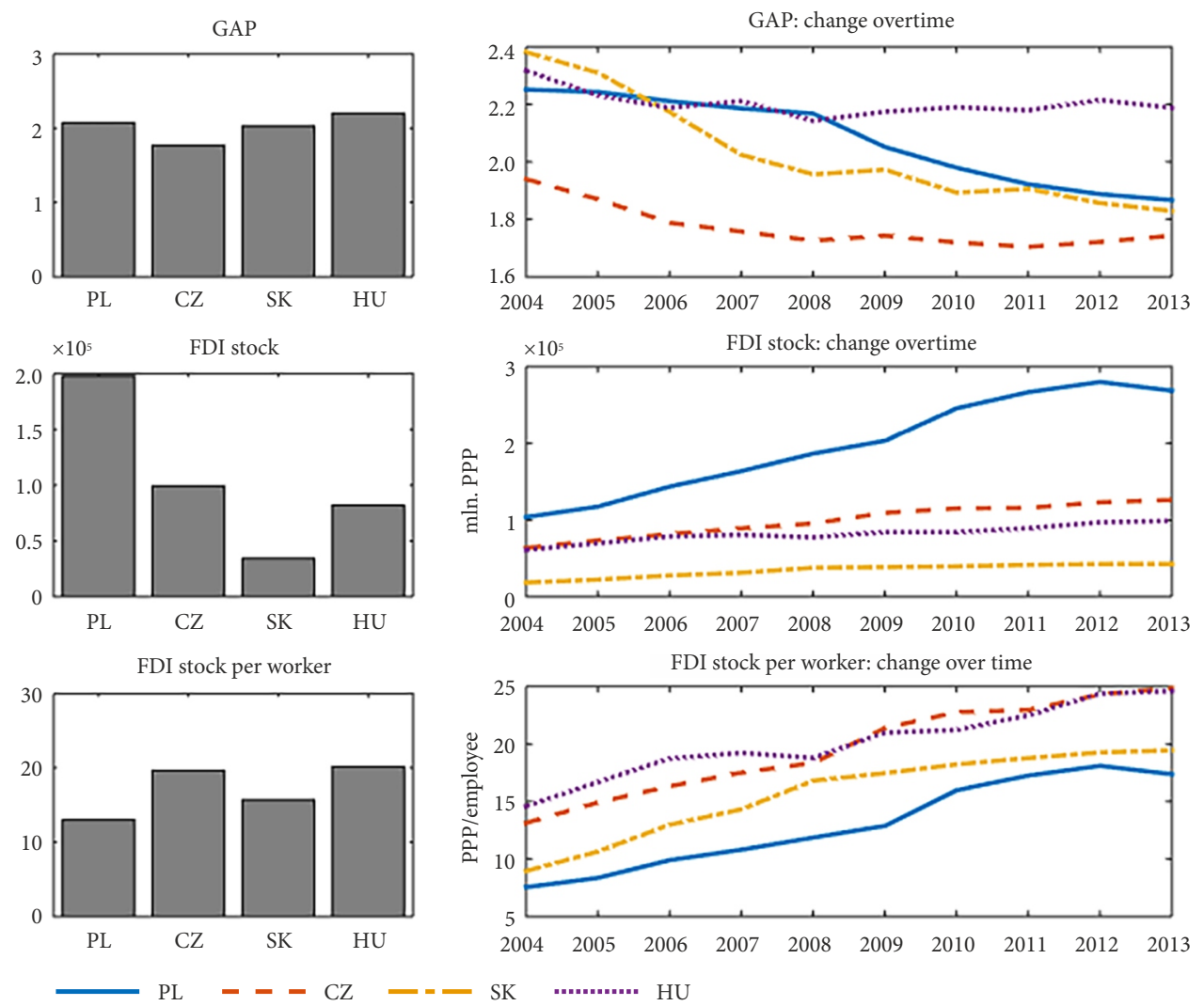

Figure 1. Basic trends in FDI and GAP in the Visegrad countries in 2004-2013

\section{Empirical findings and discussion}

\subsection{Main results and findings}

Summary results for the GTRE-VED model discussed in the previous section are provided in Table 2. We observe reasonable and precise estimates of the productions function's structural parameters, which correspond to production elasticity of effective capital and labour at the level of 0.393 and 0.276 respectively. The posterior mean of production elasticity of effective FDI $\left(\beta_{3}\right)$ is almost two posterior standard deviations away from zero indicating a definite positive "direct" impact of FDI (whose effectiveness is weighted by the technology gap) on production (Eq. (3a)) and labour productivity (Eq. (3b)). The positioning of the posterior median in relation to interquartile range (IQR) confirms this finding; most probability mass of the posterior distribution of $\beta_{3}$ is above zero. The increase in effective FDI input by 1 percentage point (p.p.) leads to an increase in sectoral production and labour productivity by $0.057 \%$ on average.

The relatively high and statistically significant positive estimate of parameter $\beta_{4}$ associated with the impact of GAP on production and labour productivity is noteworthy. The p.p. increase in GAP is accompanied by a $0.716 \%$ increase in production and labour pro- 
ductivity. Since GAP is constructed here as a distance ratio of labour productivities between the V4 and the EU15 sectors (see Eq. (5)), one can evaluate the direct impact of the EU15 labour productivity. We find that an increase in labour productivity in the EU15 by 1 p.p. is accompanied by an increase in labour productivity in V4 by $0.41 \%$ on average. This seems reasonable because growth in the EU15 sectors should translate to growth in the V4. This provides some evidence of a convergence (or catching-up) mechanism within the EU with respect to production and labour productivity, likely due to spillover effects (Sohinger, 2005; Wojciechowski, 2016a, 2016b). It would indicate that the gap closes in a convergence mechanism similar to the one discussed in Wang and Blomstrom (1992) and it confirms some of the findings in Bijsterbosch and Kolasa (2010) and Mastromarco and Simar (2014) in this regard. Also, contrary to Bijsterbosch and Kolasa (2010) or Hanafy and Marktanner (2019), the general positive effect of FDI is unconditional in the V4. This could suggest that the required stage of development, outlined in Fillat and Woerz (2011) or Barrios et al. (2005), is met in V4. Furthermore, we note a fairly precise estimate of the VED component $\left(g_{1}\right)$ which clearly suggests that an increase in FDI is associated with a decrease in the average inefficiency of resource management, i.e., an increase in efficiency and therefore TFP. The time index variable has turned out to be negligible.

Hypothesis $\mathrm{H} 1$ states that FDI has a positive influence on sectors' productivity via TFP. Results from the VED component (the estimate of parameter $g_{1}$ ) lead to the conclusion that high FDI levels are associated with high technical efficiency. Furthermore, parameters $\gamma_{0}, \gamma_{1}$ and $\gamma_{2}$ assess the impact of FDI on the effective use of capital and labour in a sector. Again, based on the respective posterior medians and interquartile ranges, we can conclude that information in the data has significantly pulled their marginal posterior distributions away

Table 2. The results of the GTRE-VED model estimation

\begin{tabular}{|l|c|c|c|c|}
\hline \multicolumn{1}{|c|}{ Parameter } & Mean & Std. & Me & IQR \\
\hline$\beta_{0}$ (intercept) & 2.786 & 0.852 & 2.776 & 1.103 \\
\hline$\beta_{1}$ (effective capital) & 0.393 & 0.093 & 0.390 & 0.121 \\
\hline$\beta_{2}$ (effective labour) & 0.276 & 0.108 & 0.289 & 0.142 \\
\hline$\beta_{3}$ (effective FDI) & 0.057 & 0.030 & 0.056 & 0.039 \\
\hline$\beta_{4}$ (GAP) & 0.716 & 0.204 & 0.692 & 0.262 \\
\hline$\beta_{5}$ (time) & 0.000 & 0.004 & $-9.45 \mathrm{E}-05$ & $5.8 \mathrm{E}-03$ \\
\hline$\gamma_{0}$ (dummy for sample av.) & $3.1 \mathrm{E}-06$ & $9.0 \mathrm{E}-07$ & $3.1 \mathrm{E}-06$ & $1.2 \mathrm{E}-06$ \\
\hline$\gamma_{1}$ (impact of FDI on capital effective input) & $8.4 \mathrm{E}-06$ & - & $7.9 \mathrm{E}-06$ & $3.7 \mathrm{E}-06$ \\
\hline$\gamma_{2}$ (impact of FDI on labour effective input) & $2.4 \mathrm{E}-05$ & - & $1.1 \mathrm{E}-05$ & $7.7 \mathrm{E}-06$ \\
\hline$\gamma_{3}$ (impact of GAP on FDI effective input) & 21.810 & - & 11.884 & 9.661 \\
\hline$g_{0}$ (dummy for sample av.) & -2.489 & 0.243 & -2.331 & 0.158 \\
\hline$g_{1}$ (impact of FDI on TFP via inefficiency decline) & -0.760 & 0.380 & -0.517 & 0.249 \\
\hline
\end{tabular}

Note: Mean is posterior mean; Std stands for posterior standard deviation; Me is posterior median; IQR stands for posterior interquartile range; posterior standard deviations for $\gamma_{1}, \gamma_{2}, \gamma_{3}$ are not provided because these parameters are acquired as ratios of other model parameters and thus their respective distributions may not have second central moments; in these cases the reader should turn to IQR for dispersion assessment. 
from the neutrally positioned priors (at zero) towards positive values. This indicates a positive impact of FDI on capital and labour effective use in production and thus productivity in general. Given the estimation results of the aforementioned parameters $\left(g_{1}, \gamma_{0}, \gamma_{1}, \gamma_{2}\right)$, we find a discerning evidence in favour of hypothesis $\mathrm{H} 1$.

According to hypothesis $\mathrm{H} 2$, the size of the technological gap should positively impact the efficiency of FDI utilization in sectoral production of the host economy. Parameter $\gamma_{3}$ in our model assesses the impact of GAP on FDI's effectiveness. Information in the data has significantly changed the posterior distribution of $\gamma_{3}$, pushing it away from the neutrally positioned prior (around zero) towards positive values. In fact, the posterior median is higher than the interquartile range, which signals that most of the probability mass is above zero. Thus, we note a positive impact of GAP on FDI utilization and hypothesis $\mathrm{H} 2$ is therefore confirmed.

To reiterate, the obtained results allow us to support hypotheses $\mathrm{H} 1$ and $\mathrm{H} 2$. Indeed, we find that increased involvement of foreign investors (measured by FDI in the V4 sectors) has an impact on the following three aspects: (i) direct impact on production and labour productivity; (ii) effective use of capital and labour inputs; and (iii) increasing TFP by reducing inefficiencies. This constitutes a three-component transmission mechanism through which FDI affects economic growth. The increased involvement of foreign capital in the V4 is, therefore, associated with both, higher labour productivity and higher total factor productivity (due to lower inefficiency). Furthermore, we also find that GAP has an influence on the effectiveness of FDI utilization in the V4 sectors.

\subsection{Robustness checks}

A question may be asked whether using a simpler GTRE model (without the VED component) brings different qualitative results. As it turns out, dropping the VED component (and, thus, not including a direct impact of FDI on TFP) leads to a noticeably higher and more accurate evaluation of the FDI parameter $\beta_{3}$; an estimate of $0.088(0.024)$ in GTRE against 0.057 (0.03) in the GTRE-VED model. So, it can be argued that the "indirect" impact of FDI on TFP (via varying efficiency parameter $g_{1}$ ) is captured in a simpler model by the "direct" impact via parameter $\beta_{3}$. The estimate of parameter $\gamma_{1}$ which assesses the impact of FDI on the effective use of capital $\left(K_{t} e^{\gamma_{1} F D I_{t}}\right)$ is also positive and precise. Some changes are observed with the parameters $\gamma_{2}, \gamma_{3}$. The estimation of $\gamma_{3}$, which assesses the impact of the technological gap on the effective use of FDI in the production process is somewhat less precise in the simpler GTRE model, but it provides similar qualitative conclusions. These estimates are also positive, which indicates a positive effect of FDI on production (and, analogously, on labour productivity). Regarding the impact of GAP on the effective use of FDI in the production process, the estimate of $\gamma_{3}$ is precise and its sign in all GTRE models seems to confirm Findlay's (1978) hypothesis about the relationship between the rate of technological progress, the technological gap and FDI.

Another way to check stability of our findings is by investigating the impact of the timeframe on our results. This is especially important for two reasons. First, as Hanousek et al. (2011) points out the timespan of the analysis matters and it is likely that a significantly shorter timespan may yield different results. Second, the analysed period covers the econom- 
ic crisis which swept through Europe, beginning around 2007-8. For this reason we have divided our panel into two 5-year subpanels: 2004-2008 (mainly pre-crisis) and 2009-2013 (post-crisis). We have then estimated our model using the subpanels and checked if the general findings are in line with the ones from the full panel; detailed results of this exercise can be viewed in Table A3 in the Appendix. As it turns out all the main findings hold. The estimate of parameter $g_{1}$ is still negative (indicating a positive impact of FDI on TFP) and estimates of $\gamma_{0}, \gamma_{1}, \gamma_{2}$ parameters are positive indicating a positive impact of FDI on effective use of the main inputs. Also, the estimate of $\gamma_{3}$ remains positive indicating a positive impact of GAP on the effective use of FDI.

Finally, we simplify the model structure and ascertain if the general findings still hold (e.g., positive impact of FDI and GAP on economic growth). In order to do so we employ quantile regression $(\mathrm{QR})$ to check if any of the quantiles of the simplified model's coefficients contest our conclusions from the full GTRE-VED. Figure 2 presents $95 \%$ confidence intervals for QR coefficients as functions of quantiles. The results confirm our key findings from the
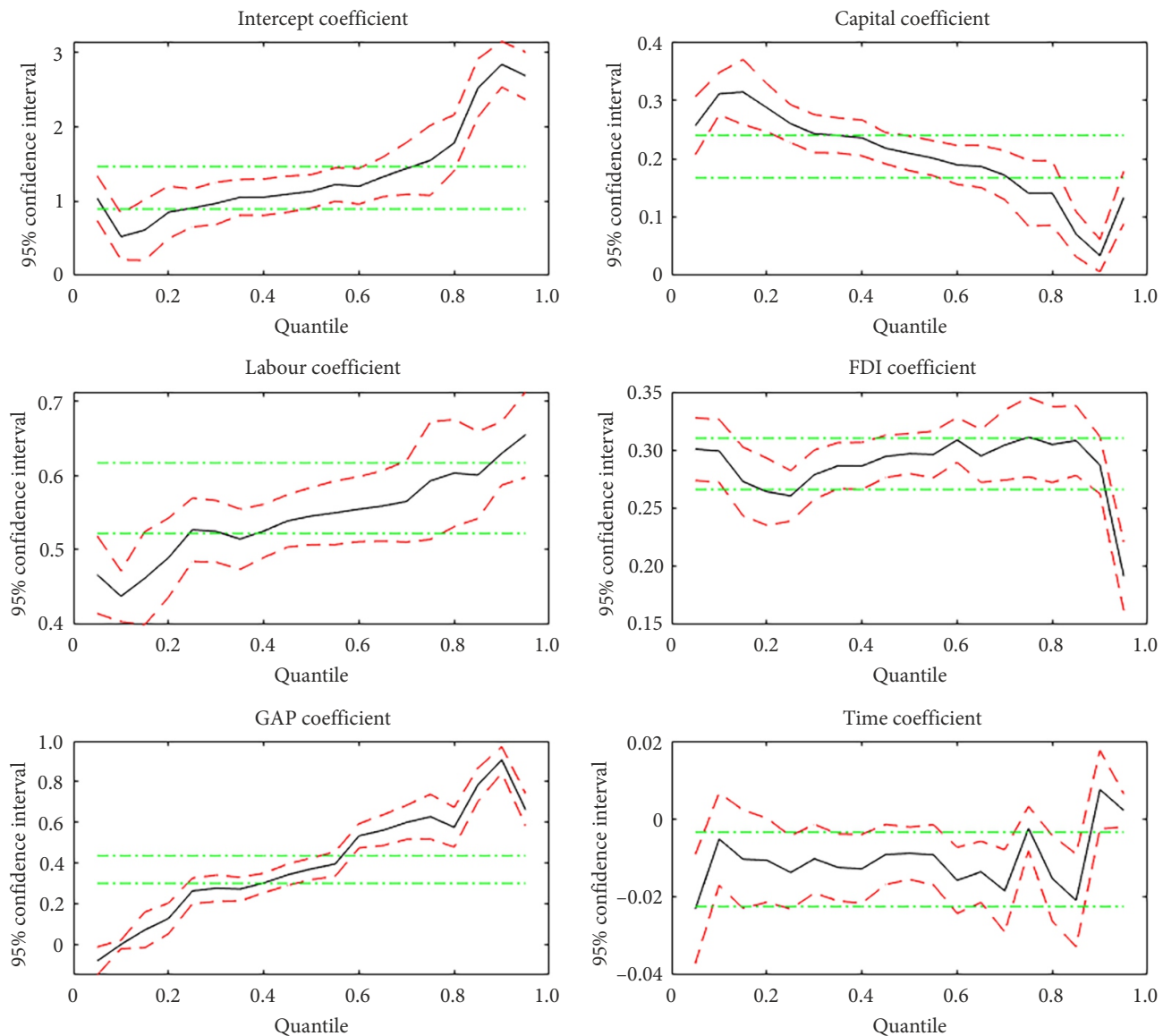

Figure 2. Quantile regression results for 0.5-095 quantiles; solid line: QR point estimate; dashed line: 95\% confidence interval; horizontal dash-dotted line: 95\% confidence intervals based on OLS 
GTRE-VED model: a positive relationship between FDI, GAP and economic growth. That is, we report a positive and statistically significant relationship throughout all quantiles (apart from GAP coefficient in which the $95 \%$ interval for 0.05 and 0.1 quantile encompasses zero; but it does not change the general conclusion). These results also do not contest the technological gap convergence (or catching up) effect discussed earlier. Since some of quantile estimates change quite significantly (in comparison to the OLS 95\% confidence band: horizontal dash-dot lines) we also note some substantial heterogeneity (and possible inefficiency) in the data. Of course, this is to be expected given the structure of the dataset (different countries and sectors) and reconfirms our use of the GTRE-VED model structure. Unfortunately, this is so far comparison with quantile QR can take us as the variables' coefficients are not directly comparable between the two approaches. This is because QR used here: (i) does not account for long-term and short term inefficiency in the production process (which is something that we find crucial in this study); (ii) does not account for panel data structure of the dataset (explicit structural heterogeneity between sectors and countries is obvious); and (iii) does not account for effective factor corrections. In a recent paper Tsionas (2020) has proposed quantile stochastic frontier models and Bayesian inference, with Gibbs sampling algorithm, to estimate it. Since the procedures used here are similar it would be probably possible to build a quantile regression for the GTRE-VED model. This, however, would likely require more advanced numerical algorithms like the ones discussed in Makieła and Mazur (2020b), which is beyond the scope of an application-oriented study such as this one.

\subsection{A note on efficiency estimates}

Efficiency estimates based on GTRE-VED model are presented in Figure 3. As we can see, the analysed V4 sectors are highly diverse in terms of the persistent efficiency levels. There is as much variation between sectors within a country as there is within a given sector but between countries. The least efficient sectors are "mining and quarrying", "water supply, sewerage, waste management and remediation activities", "electricity, gas, steam and air conditioning supply", "real estate activities" and "agriculture, forestry and fishing" (with a notable exception of agriculture in case of Slovakia). The most efficient sectors are "construction", "wholesale and retail trade", "information and communication", "financial and insurance activities" and "professional, scientific and technical activities". The above results are generally not surprising as one would expect industries such as water/sewerage, electricity, agriculture or mining to underperform, e.g., due to heavy governmental regulations or capital requirements. It is also not surprising that "modern" sectors related to information and communication, financial services and professional activities thrive in the open EU market.

There were also some significant changes in transient efficiency over time. In fact, only two sectors in Slovakia and one in Poland - "mining and quarrying" - recorded a negative change in transient efficiency. These results are especially grim for the Polish sector as mining is currently in deep recession. Though it was a relatively efficient sector at the time of the analysis (as compared to other mining sectors) its current downfall has been evidently long coming, no doubt due to bad management and ineffective governmental interventions. Similar efficiency declines can be observed in a number of sectors in the Czech Republic and Hungary, which have experienced a decline in transient efficiency after joining the EU. 


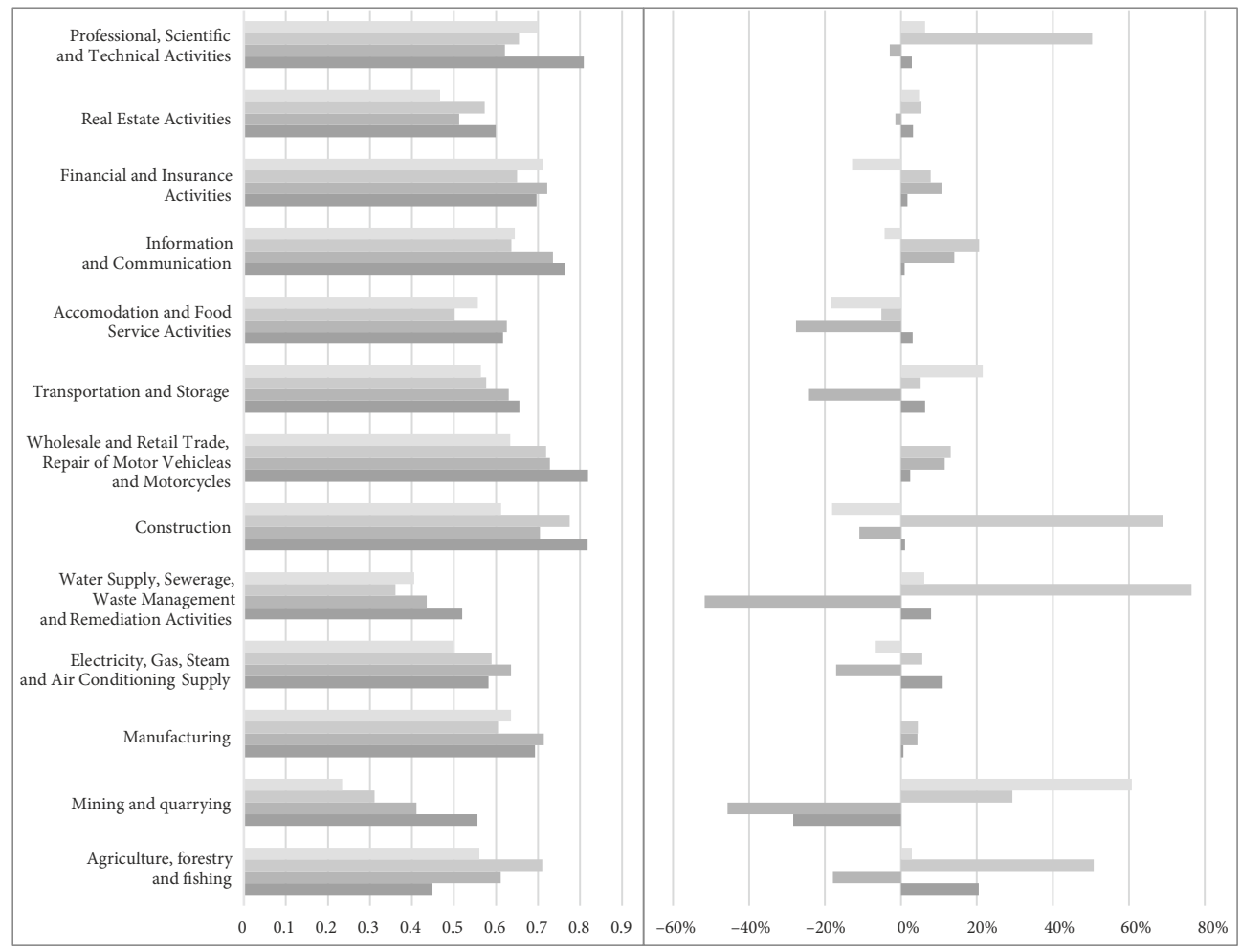

HU $\square \mathrm{SL} \square \mathrm{CZ} \square \mathrm{PL}$

Figure 3. Persistent technical efficiency levels (left chart) and transient technical efficiency change (right chart) in 2004-2013

Most notable changes have been observed (also) in "mining and quarrying" (Czech Republic), "water and waste management" (Czech Republic), "accommodation and food services" (Hungary and Czech Republic) and "construction" (Hungary).

To sum up, Polish sectors have been, on average, the most efficient ones while sectors in Slovakia have experienced the biggest growth in transient efficiency in the analysed period. Furthermore, given the main results in the previous section, it is worth noting that sectoral persistent efficiency is positively correlated with average FDI levels (spearman rank correlation equal 0.56 ), which would indicate that FDI is usually more present in those sectors of a host economy which are relatively efficient. This corresponds with one of our main findings based on the estimate of parameter $g_{1}$, which indicates that (transient) efficiency growth coincides with increasing FDI presence. Thus, it seems that FDI gravitates towards those sectors of a host economy which are relatively efficient and/or gaining efficiency. 


\section{Conclusions}

The aim of this study was to contribute to the discussion on an interplay between FDI, productivity and economic growth, especially at the sectoral level. Our econometric modelling approach has allowed us to research two hypotheses which are of much interest in the field. First, empirical studies have been largely inconclusive as regards the exact relationship between FDI, economic growth and, especially, productivity. We find that increased involvement of foreign investors in sectors of the host countries is indeed associated with an increased labour productivity and the total factor productivity. We find that the overall transmission mechanism of FDI to economic growth has three components: one direct and two indirect. The direct one is associated with the role of FDI as a relevant, nonnegligible factor of production. The first indirect component is due to FDI's role in making the "basic" production factors (capital and labour) more effective while the second one is due to the role FDI plays in increasing total factor productivity (by decreasing technical inefficiency). In case of V4 a substantial positive relationship is found both, in terms of total factor productivity as well as in the higher efficiency of "basic" production factors. Also, FDI's impact on the host economy at the sectoral level is well visible.

Second, we confirm the hypothesis about the interplay between technological progress, the technological gap and FDI. In doing so, we also notice some evidence in favour of the notion of labour productivity convergence, or catching-up, between the "old" and the "new" member states of the EU. We find that though the technological gap increases FDI's effectiveness, the general positive effect of FDI is not conditioned on the gap, nor on any other absorptive capacity indicator in particular. This could suggest that the V4 group has the required stage of development for FDI's positive spillovers to occur unconditionally.

The obtained results are thus encouraging to conduct more in-depth sectoral level analyses, especially in those sectors where the impact of foreign capital is substantial and the inflow of new technologies is nonnegligible. Since sectoral level data are becoming increasingly available it is likely that such analyses will be more popular in future. Moreover, given our results a number of policy implications can be drawn. First, policymakers in the V4 should continue to encourage foreign investors because positive FDI spillovers in the V4 region (direct and indirect) are clearly evident. Second, in order to maximize potential returns on FDI, policies should be drawn to target sectors with substantial differences in labour productivity (between the host and home sectors) because these are areas which are the most likely to bring substantial benefits from both direct and indirect FDI spillovers. Third, policymakers should also focus their attention on sectors of the V4 economies, which have relatively low persistent efficiency or experience a substantial decline in transient efficiency. These are areas where potential gains from FDI might be stifled by market inefficiency and thus, foreign investors may choose to withdraw.

One of the limitations of the study was the lack of reliable sectoral purchasing power parity deflators. An important issue was also the availability of appropriate proxies for fixed capital and labour at the sectoral level, and that FDI is accounted for in fixed capital to some (unknown) extent (though correlation between FDI and physical capital in this study is small, so there is no issue of collinearity). Another bottleneck was the lack of relevant 
cross-country absorptive capacity indicators measured at the sectoral level apart from the technological gap. Although we still found discerning evidence of positive FDI spillovers, other (sectoral level) absorptive capacity indicators may reveal even higher FDI influence at the sectoral level.

\section{Acknowledgements}

We would like to thank Mark C. Hoffman for his comments in preparing the article.

\section{Funding}

The first author was supported by National Science Centre, Poland (NCN) under Grant: UMO-2018/31/B/HS4/01565. The second author was supported by National Science Centre, Poland (NCN) under Grant: UMO-2015/17/N/HS4/01528.

\section{Author contributions}

K.M., L.W. and K.W. contributed equally to this work in the following aspects: conceptualization; validation; formal analysis; methodology; investigation; resources; writing-original draft preparation; visualization; supervision; project administration. Additionally, L.W. contributed: data curation; and K.M. contributed: software.

\section{Disclosure statement}

The authors declare no competing financial, professional, or personal interests from other parties.

\section{References}

Alfaro, L., Kalemli-Ozcan, S., \& Sayek, S. (2009). FDI, productivity and financial development. The World Economy, 32(1), 111-135. https://doi.org/10.1111/j.1467-9701.2009.01159.x

Almfraji, M. A., \& Almsafir, M. K. (2014). Foreign direct investment and economic growth literature review from 1994 to 2012. Procedia - Social and Behavioural Sciences, 129, 206-213. https://doi.org/10.1016/j.sbspro.2014.03.668

Apostolov, M. (2016). Cobb-Douglas production function on FDI in Southeast Europe. Journal of Economic Structures, 5(10), 1-28. https://doi.org/10.1186/s40008-016-0043-x

Azman, W. N. W., Baharumshah, A. Z., \& Law, S. H. (2010). Foreign direct investment, economic freedom and economic growth: International evidence. Economic Modelling, 27, 1079-1089. https://doi.org/10.1016/j.econmod.2010.04.001

Badunenko, O., \& Kumbhakar, S. (2016). When, where and how to estimate persistent and transient efficiency in stochastic frontier panel data models. European Journal of Operational Research, 255(1), 272-287. https://doi.org/10.1016/j.ejor.2016.04.049

Barrell, R., \& Holland, D. (2000). Foreign direct investment and enterprise restructuring in Central Europe. Economics of Transition, 8(2), 477-504. https://doi.org/10.1111/1468-0351.00052 
Barrios, S., Gorg, H., \& Strobl., E. (2005). Foreign direct investment, competition and industrial development in the host country. European Economic Review, 49(7), 1761-1784.

https://doi.org/10.1016/j.euroecorev.2004.05.005

Bijsterbosch, M., \& Kolasa, M. (2010). FDI and productivity convergence in Central and Eastern Europe: an industry-level investigation. Review of World Economics, 145, 689-712.

https://doi.org/10.1007/s10290-009-0036-Z

Cipollina, M., Giovannetti, G., Pietrovito, F., \& Pozzolo, A. (2012). FDI and growth: What crosscountry industry data say. The World Economy, 35(11), 1599-1629.

https://doi.org/10.1111/j.1467-9701.2012.01478.x

Colombi, R., Kumbhakar, S. C., Martini, G., \& Vittadini, G. (2014) Closed-skew normality in stochastic frontiers with individual effects and long/short-run efficiency. Journal of Productivity Analysis, 42(2), 123-136. https://doi.org/10.1007/s11123-014-0386-y

Djankov, S., \& Hoekman, B. (2000). Foreign investment and productivity growth in Czech enterprises. World Bank Economic Review, (14), 49-64. https://doi.org/10.1093/wber/14.1.49

Doytch, N., \& Uctum, M. (2011). Does the worldwide shift of FDI from manufacturing to services accelerate economic growth? A GMM estimation study. Journal of International Money and Finance, 30(3), 410-427. https://doi.org/10.1016/j.jimonfin.2011.01.001

Dunning, J. (1973). The determinants of international production. Oxford Economic Papers, 25(3), 289-336. https://doi.org/10.1093/oxfordjournals.oep.a041261

Durham, J. B. (2004). Absorptive capacity and the effects of foreign direct investment and equity foreign portfolio investment on economic growth. European Economic Review, 48(2), 285-306. https://doi.org/10.1016/S0014-2921(02)00264-7

Egger, P., \& Pfaffermayr, M. (2001). A note on labour productivity and foreign inward direct investment. Applied Economics Letters, 8(4), 229-232. https://doi.org/10.1080/135048501750103917

Filippini, M., \& Greene, W. (2016). Persistent and transient productive inefficiency: a maximum simulated likelihood approach. Journal of Productivity Analysis, 45(2), 187-196. https://doi.org/10.1007/s11123-015-0446-y

Fillat, C., \& Woerz, J. (2011). Good or bad? The influence of FDI on productivity growth. An industry level analysis. Journal of International Trade and Economic Development, 20(3), 293-328. https://doi.org/10.1080/09638190903003010

Findlay, R. (1978). Relative Backwardness, direct foreign investment, and the transfer of technology: A simple dynamic model. The Quarterly Journal of Economics, 92(1), 1-16. https://doi.org/10.2307/1885996

Fried, H. O., Lovell, C. A. K., \& Schmidt, S. S. (2008). The measurement of productive efficiency and productivity growth. Oxford University Press. https://doi.org/10.1093/acprof:oso/9780195183528.001.0001

Glass, A. J., \& Saggi, K. (1998). International technology transfer and the technology gap. Journal of Development Economics, 55, 369-398. https://doi.org/10.1016/S0304-3878(98)00041-8

Gunther, J., \& Kristalova, M. (2016). No risk, no fun? Foreign direct investment in Central and Eastern Europe. Intereconomics, 51(2), 95-99. https://doi.org/10.1007/s10272-016-0583-1

Hanafy, S., \& Marktanner, M. (2019). Sectoral FDI, absorptive capacity and economic growth - empirical evidence from Egyptian governorates. The Journal of International Trade \& Economic Development, 28(1), 57-81. https://doi.org/10.1080/09638199.2018.1489881

Hanousek, J., Kocenda, E., \& Maurel, M. (2011). Direct and indirect effects of FDI in emerging European markets: A survey and meta-analysis. Economic Systems, 35(3), 301-322.

https://doi.org/10.1016/j.ecosys.2010.11.006

Haskel, J., Pereira, S., \& Slaughter, M. (2007). Does inward foreign direct investment boost the productivity of domestic firms? The Review of Economics and Statistics, 89(3), 482-496.

https://doi.org/10.1162/rest.89.3.482 
Hirschman, A. (1958). The strategy of economic development. Yale University Press.

Hong, J., Zhou, C., Wu, Y., Wang, R., \& Marinova, D. (2019). Technology gap, reverse technology spillover and domestic innovation performance in outward foreign direct investment: Evidence from China. China \& World Economy, 27, 1-23. https://doi.org/10.1111/cwe.12272

Iamsiraroj, S., \& Ulubasoglu, M. A. (2015). Foreign direct investment and economic growth: a real relationship or wishful thinking? Economic Modelling, 51, 200-213.

https://doi.org/10.1016/j.econmod.2015.08.009

Javorcik, B. S. (2004). Does foreign direct investment increase the productivity of domestic firms? In search of spillovers through backward linkages. American Economic Review, 94(3), 605-627. https://doi.org/10.1257/0002828041464605

Javorcik, B. S. \& Spatareanu, M. (2011). Does it matter where you come from? Vertical spillovers from foreign direct investment and the origin of investors. Journal of Development Economics, 96(1), 126-138. https://doi.org/10.1016/j.jdeveco.2010.05.008

Javorcik, B. S., Lo Turco, A., \& Maggioni, D. (2018). New and improved: Does FDI boost production complexity in host countries? The Economic Journal, 128(614), 2507-2537. https://doi.org/10.1111/ecoj.12530

Jiang, W., Martek, I., Hosseini, M. R., Tamošaitienè, J., \& Chen, C. (2019). Foreign infrastructure investment in developing countries: a dynamic panel data model of political risk impacts. Technological and Economic Development of Economy, 25(2), 134-167. https://doi.org/10.3846/tede.2019.7632

Kokko A., Tansinis, R., \& Zeman, M. C. (1996). Local technological capability and productivity spillovers from FDI in the Uruguayan manufacturing sector. Journal of Development Studies, 32. https://doi.org/10.1080/00220389608422430

Kolasa, M. (2008). How does FDI inflow affect productivity of domestic firms? The role of horizontal and vertical spillovers, absorptive capacity and competition. The Journal of International Trade \& Economic Development, 17(1), 155-173. https://doi.org/10.1080/09638190701728131

Konings, J. (2001). The effects of foreign direct investment on domestic firms. Evidence from firm-level panel data in emerging economies. Economics of Transition, 9(3), 619-633. https://doi.org/10.1111/1468-0351.00091

Koop, G., Osiewalski, J., \& Steel, M. F. (2000). Modelling the sources of output growth in a panel of countries. Journal of Business \& Economic Statistics, 18, 284-299. https://doi.org/10.1080/07350015.2000.10524871

Koop, G., Osiewalski, J., \& Steel, M. F. J. (1994). Hospital efficiency analysis through individual effects: a Bayesian approach (Discussion Paper No. 9447). Center for Economic Research.

Koop, G., Osiewalski, J., \& Steel, M. F. J. (1997). Bayesian efficiency analysis through individual effects: Hospital cost frontiers. Journal of Econometrics, 76, 77-105. https://doi.org/10.1016/0304-4076(95)01783-6

Kosztowniak, A. (2013). Foreign direct investment as a factor of economic growth in Poland. Empirical analysis for the period 1995-2012. Advances in Economics and Business, 1(2), 203-212.

Li, C., \& Tanna, S. (2019). The impact of foreign direct investment on productivity: New evidence for developing countries. Economic Modelling, 80, 453-466. https://doi.org/10.1016/j.econmod.2018.11.028

Lin, C., Lee, C., \& Yang, C. (2011). Does foreign direct investment really enhance China's regional productivity? The Journal of International Trade \& Economic Development, 20(6), 741-768. https://doi.org/10.1080/09638190903294866

Liu, Z. (2008). Foreign direct investment and technology spillovers: Theory and evidence. Journal of Development Economics, 85(1), 176-193. https://doi.org/10.1016/j.jdeveco.2006.07.001

Liu, W. S., Agbola, F. W., \& Dzator, J. A. (2016). The impact of FDI spillover effects on total factor productivity in the Chinese electronic industry: a panel data analysis. Journal of the Asia Pacific Economy, 21(2), 217-234. https://doi.org/10.1080/13547860.2015.1137473 
MacDougall, G. D. A. (1960). The benefits and costs of private investment from abroad. Economic Record, 36, 13-35. https://doi.org/10.1111/j.1475-4932.1960.tb00491.x

Makieła, K. (2014). Bayesian stochastic frontier analysis of economic growth and productivity change in the EU, USA, Japan and Switzerland. Central European Journal of Economic Modelling and Econometrics, 6(3), 193-216.

Makieła, K. (2017a). Bayesian inference and Gibbs sampling in generalized true random-effects models. Central European Journal of Economic Modelling and Econometrics, 9(1), 69-95.

Makieła, K. (2017b). Bayesian stochastic frontier analysis with MATLAB (Working Paper). https://doi.org/10.13140/RG.2.2.24520.06403

Makieła, K., \& Mazur, B. (2020a). Bayesian model averaging and prior sensitivity in stochastic frontier analysis. Econometrics, 8(2), 13. https://doi.org/10.3390/econometrics8020013

Makieła, K., \& Mazur, B. (2020b). Stochastic frontier analysis with generalized errors: inference, model comparison and averaging. http://arxiv.org/abs/2003.07150

Makieła, K., \& Misztur, T. (2012). Going green versus economic performance. Engineering Economics, 23(2), 137-143. https://doi.org/10.5755/j01.ee.23.2.1546

Makieła, K., \& Ouattara, B. (2018). Foreign direct investment and economic growth: Exploring the transmission channels. Economic Modelling, 72, 296-305. https://doi.org/10.1016/j.econmod.2018.02.007

Mallick, S., \& Moore, T. (2008). Foreign capital in a growth model. Review of Development Economics, 12(1), 143-159. https://doi.org/10.1111/j.1467-9361.2008.00437.x

Marzec, J., \& Osiewalski, J. (2008). Bayesian inference on technology and cost efficiency of bank branches. Bank and Credit, 39(9), 29-43.

Mastromarco, C., \& Ghosh, S. (2009). Foreign capital, human capital, and efficiency: A stochastic frontier analysis for developing countries. World Development, 32(2), 489-502. https://doi.org/10.1016/j.worlddev.2008.05.009

Mastromarco, C., \& Simar, S. (2014). Effect of FDI and time on catching up: New insights from a conditional nonparametric frontier analysis. Journal of Applied Econometrics, 30(5), 826-847. https://doi.org/10.1002/jae.2382

Melnyk, L., Kubatko, O., \& Pysarenko, S. (2014). The impact of foreign direct investment on economic growth: case of post communism transition economies. Problems and Perspectives in Management, 12(1).

Meyer, K. E., \& Sinani, E. (2009). When and where does foreign direct investment generate positive spillovers? A meta-analysis. Journal of International Business Studies, 40(7), 1075-1094.

https://doi.org/10.1057/jibs.2008.111

Olislager, L., \& Knijno, P. (2017). Estimating purchasing power parities for the production side of GDP. Eurostat EURONA - Eurostat Review on National Accounts and Macroeconomic Indicators. https://ec.europa.eu/eurostat/cros/system/files/euronaissue2-2016-art3.pdf

Orlic, E., Hashi, I., \& Hisarciklilar, M. (2018). Cross sectoral FDI spillovers and their impact on manufacturing productivity. International Business Review, 27(4), 777-796. https://doi.org/10.1016/j.ibusrev.2018.01.002

Osiewalski, J., Wróblewska, J., \& Makieła, K. (2018). Bayesian comparison of production function-based and time-series GDP models. Empirical Economics. https://doi.org/10.1007/s00181-018-1575-8

Sgard, J. (2001). Direct foreign investments and productivity growth in Hungarian firms, 1992-1999. https://doi.org/10.2139/ssrn.293696

Sohinger, J. (2005). Growth and convergence in European transition economies: The impact of foreign direct investment. Eastern European Economics, 43(2), 73-94. https://doi.org/10.1080/00128775.2005.11041099

Stancik, J. (2010). FDI spillovers in the Czech Republic: Takeovers versus greenfields. In F. Keereman, \& I. Szekely (Eds.), Five years of an enlarged EU. Springer, Berlin, Heidelberg. https://doi.org/10.1007/978-3-642-12516-4_3 
Su, W., Zhang, D., Zhang, C., Abrhám, J., Simionescu, M., Yaroshevich, N., \& Guseva, V. (2018). Determinants of foreign direct investment in the Visegrad group countries after the EU enlargement. Technological and Economic Development of Economy, 24(5), 1955-1978. https://doi.org/10.3846/tede.2018.5487

Thompson, H. (2008). Economic growth with foreign capital. Review of Development Economics, 12(4), 694-701. https://doi.org/10.1111/j.1467-9361.2008.00395.x

Tsionas, M. (2020). Quantile stochastic frontiers. European Journal of Operational Research, 282(3), 1177-1184. https://doi.org/10.1016/j.ejor.2019.10.012

Tsionas, M., \& Kumbhakar, S. (2014). Firm heterogenity, persistent and transient technical inefficiency: A generalized true random-effects model. Journal of Applied Econometrics, 29(1), 110-132. https://doi.org/10.1002/jae.2300

Tsionas, M., \& Mallick, S. (2019). A Bayesian semiparametric approach to stochastic frontiers and productivity. European Journal of Operational Research, 274, 391-402. https://doi.org/10.1016/j.ejor.2018.10.026

Vu, T. B., \& Noy, I. (2009). Sectoral analysis of foreign direct investment and growth in the developed countries. Journal of International Financial Markets, Institutions and Money, 19(2), 402-413. https://doi.org/10.1016/j.intfin.2008.04.002

Wach, K., \& Wojciechowski, L. (2016a). Determinants of inward FDI into Visegrad countries: empirical evidence based on panel data for the years 2000-2012. Economics and Business Review, 2(1). https://doi.org/10.18559/ebr.2016.1.3

Wach, K., \& Wojciechowski, L. (2016b). Inward FDI and entrepreneurship rate: Empirical evidence on selected effects of FDI in Visegrad countries. Journal of Economics and Management, 24(2), 42-54. https://doi.org/10.22367/jem.2016.24.04

Wang, J.-Y., \& Blomstrom, M. (1992). Foreign investment and technology transfer: A simple model. European Economic Review 36(1), 137-155. https://doi.org/10.1016/0014-2921(92)90021-N

Wojciechowski, L. (2016a). Foreign Direct Investment as a stimulant in productivity convergence process between Visegrad Countries and EU-15. Acta Universitatis Lodziensis. Folia Oeconomica, 6(326), 163-180. https://doi.org/10.18778/0208-6018.326.11

Wojciechowski, L. (2016b). The impact of FDI on gross value added in host country with particular emphasis on manufacturing sector. Studies of the Industrial Geography Commission of the Polish Geographical Society, 30(1), 143-158.

Wojciechowski, L., \& Makieła, K. (2019). Determinants of foreign direct investments in the Visegrad group countries. Acta Universitatis Lodziensis. Folia Oeconomica, 4(343), 103-121. https://doi.org/10.18778/0208-6018.343.07

Żukowska-Gagelmann, K. (2000). Productivity spillovers from foreign direct investment in Poland. Economic Systems, 24(3), 223-256. https://doi.org/10.1007/s001830000046 


\section{APPENDIX}

Table A1. Characteristics of the data used in the production function (the first equation)

\begin{tabular}{|l|c|l|l|l|}
\hline Category & Variable & \multicolumn{1}{|c|}{ Unit } & \multicolumn{1}{|c|}{ Source } & \multicolumn{1}{|c|}{ Comments } \\
\hline $\begin{array}{l}\text { Foreign } \\
\text { direct } \\
\text { investment }\end{array}$ & FDI & $\begin{array}{l}\text { The cumulative value of foreign } \\
\text { investments (in millions; real } \\
\text { chained linked PPPs, 2005 base). }\end{array}$ & $\begin{array}{l}\text { V4's central } \\
\text { banks (NBP, } \\
\text { CNB, MNB, } \\
\text { SNB), Eurostat }\end{array}$ & $\begin{array}{l}\text { Lack of sectoral PPP } \\
\text { deflators. }\end{array}$ \\
\hline Production & Q & $\begin{array}{l}\text { Sectoral gross value added (in } \\
\text { millions; real chained linked PPPs, } \\
\text { 2005 base). }\end{array}$ & Eurostat & $\begin{array}{l}\text { Lack of sectoral PPP } \\
\text { deflators. }\end{array}$ \\
\hline Capital & K & $\begin{array}{l}\text { Gross fixed capital value in } \\
\text { replacement costs (in millions; } \\
\text { real chained linked PPPs, 2005 } \\
\text { base). }\end{array}$ & Eurostat & $\begin{array}{l}\text { Lack of sectoral PPP } \\
\text { deflators. No data } \\
\text { for Slovakia for the } \\
\text { period 1995-2003. }\end{array}$ \\
\hline Labour & L & $\begin{array}{l}\text { - number of hours worked. } \\
- \text { number of people employed. }\end{array}$ & Eurostat & $\begin{array}{l}\text { No data for Hungary } \\
\text { for the period 1995- } \\
\text { 2009 and for Poland } \\
\text { 1995-2000. }\end{array}$ \\
\hline $\begin{array}{l}\text { Technology } \\
\text { gap }\end{array}$ & GAP & $\begin{array}{l}\text { Ratio of partial productivity of } \\
\text { labour in V4 country } i \text { in industry } \\
j \text { and period } t \text { divided by the } \\
\text { corresponding EU15 average. }\end{array}$ & - & - \\
\hline
\end{tabular}

Note: FDI and K variables were originally in national currencies; for those variables appropriate deflators have been used to make them comparable with real GVA.

Table A2. National economy by sectors NACE rev.2

\begin{tabular}{|l|c|}
\hline \multicolumn{1}{|c|}{ Description } & NACE code \\
\hline Agriculture, forestry and fishing & A \\
\hline Mining and quarrying & B \\
\hline Manufacturing & C \\
\hline Electricity, Gas, Steam and Air Conditioning Supply & D35 \\
\hline Water Supply; Sewerage, Waste Management and Remediation Activities & E \\
\hline Construction & F \\
\hline Total Services & GTU \\
\hline Wholesale and Retail Trade; Repair of Motor Vehicles and Motorcycles & G \\
\hline Transportation and Storage & H \\
\hline Accommodation and Food Service Activities & I \\
\hline Information and Communication & J \\
\hline Financial and Insurance Activities & K \\
\hline Real Estate Activities & L \\
\hline Professional, Scientific and Technical Activities & M \\
\hline Total & FDI_T \\
\hline
\end{tabular}

Note: Aggregates given in italic were analysed separately. 
Table A3. Results from the two subpanels

\begin{tabular}{|c|c|c|c|c|c|c|c|c|}
\hline & \multicolumn{3}{|c|}{ Results from 2004-2008 subpanel } & \multicolumn{3}{c|}{ Results from 2009-2013 subpanel } \\
\hline Par. & Mean & Std. & Me & IQR & Mean & Std. & Me & IQR \\
\hline$\beta_{0}$ & 2.293 & 0.598 & 2.294 & 0.796 & 2.017 & 0.873 & 2.000 & 1.124 \\
\hline$\beta_{1}$ & 0.292 & 0.064 & 0.290 & 0.083 & 0.288 & 0.091 & 0.287 & 0.121 \\
\hline$\beta_{2}$ & 0.473 & 0.057 & 0.474 & 0.074 & 0.534 & 0.086 & 0.534 & 0.113 \\
\hline$\beta_{3}$ & 0.150 & 0.035 & 0.149 & 0.046 & 0.133 & 0.041 & 0.132 & 0.051 \\
\hline$\beta_{4}$ & 0.353 & 0.155 & 0.336 & 0.201 & 0.818 & 0.273 & 0.784 & 0.360 \\
\hline$\beta_{5}$ & -0.001 & 0.007 & -0.001 & 0.009 & 0.007 & 0.007 & 0.007 & 0.009 \\
\hline$\gamma_{0}$ & $3.25 \mathrm{E}-06$ & $1.65 \mathrm{E}-06$ & $3.26 \mathrm{E}-06$ & $2.16 \mathrm{E}-06$ & $1.18 \mathrm{E}-06$ & $1.47 \mathrm{E}-06$ & $1.16 \mathrm{E}-06$ & $1.94 \mathrm{E}-06$ \\
\hline$\gamma_{1}$ & $1.17 \mathrm{E}-05$ & - & $1.11 \mathrm{E}-05$ & $7.94 \mathrm{E}-06$ & $4.91 \mathrm{E}-06$ & - & $4.01 \mathrm{E}-06$ & $7.15 \mathrm{E}-06$ \\
\hline$\gamma_{2}$ & $7.10 \mathrm{E}-06$ & - & $6.90 \mathrm{E}-06$ & $5.01 \mathrm{E}-06$ & $2.28 \mathrm{E}-06$ & - & $2.17 \mathrm{E}-06$ & $3.68 \mathrm{E}-06$ \\
\hline$\gamma_{3}$ & 2.392 & - & 2.267 & 1.199 & 7.008 & - & 5.868 & 3.141 \\
\hline$g_{1}$ & -2.589 & 0.187 & -2.561 & 0.235 & -2.748 & 0.204 & -2.748 & 0.311 \\
\hline$g_{2}$ & -0.337 & 0.222 & -0.285 & 0.208 & -0.614 & 0.285 & -0.583 & 0.549 \\
\hline
\end{tabular}

Note: Par. is model parameter; Mean is posterior mean; Std stands for posterior standard deviation; Me is posterior median; IQR stands for posterior interquartile range; posterior standard deviations for $\gamma_{1}, \gamma_{2}, \gamma_{3}$ are not provided because these parameters are acquired as ratios of other model parameters and thus their respective distributions may not have second central moments; the reader should turn to IQR for dispersion assessment. 